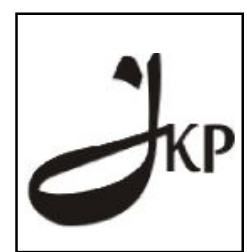

Info Artikel:

Diterima 04/06/2014

Direvisi 13/06/2014

Dipublikasikan 30/06/2014
Jurnal Konseling dan Pendidikan

ISSN Cetak: 2337-6740 - ISSN Online: 2337-6880

http://jurnal.konselingindonesia.com

Volume 2 Nomor 2, Juni 2014, HIm 19-24

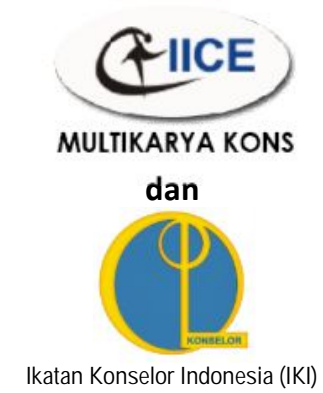

\title{
Urgensi Peranan Keluarga bagi Perkembangan Self-Esteem Remaja
}

Nikmarijal \& Ifdil

Universitas Negeri Padang

Abstract

Adolescence is the period of interest due to their properties and its role in determining the life of society. The one that affects its development is self-esteem. Self-esteem is formed through the interaction of individuals with their environment. One family environment, if the environment providing something fun, self-esteem would be positive, but if its not fun and self-esteem will be negative, further support parents, parental control, and relationship to each other between the parents give a direct influence on the development of adolescent self-esteem. This article will expose further the importance of the role of the family in developing the self-esteem of teenage.

Keyword: Self-esteem, Remaja, Keluarga, Orangtua

Copyright $\odot 2014$ IICE - Multikarya Kons (Padang - Indonesia) dan IKI - Ikatan Konselor Indonesia - All Rights Reserved Indonesian Institute for Counseling and Education (IICE) Multikarya Kons

\section{PENDAHULUAN}

Self-esteem merupakan salah satu faktor keberhasilan individu dalam kehidupannya, karena perkembangan self-esteem pada anak-anak akan menentukan keberhasilan maupun kegagalan di masa mendatang. Sebagai penilaian terhadap diri sendiri, maka pengembangan self-esteem menjadi bagian penting dalam pendidikan karena diharapkan mampu memproses penemuan konsep diri positif pada jiwa anak. Menurut branden (2005) self-esteem adalah (1) keyakinan dan kemampuan untuk bertindak dan menghadapi tantangan hidup ini, (2) keyakinan dalam hak untuk bahagia, perasaan berharga, layak. Memungkinkan untuk menegaskan kebutuhankebutuhan dan keinginan-keinginan.

Coopersmith (1967) juga menungkapkan self-esteem merupakan evaluasi yang dibuat individu dan kebiasaan memandang dirinya terutama mengenai sikap menerima dan menolak, juga indikasi bersarnya kepercayaan individu terhadap kemampuannya, keberartian, kesuksesan, dan keberhargaan. Secara singkat selfesteem adalah "personal judgment" mengenai perasaan berharga atau berarti yang diekspresikan dalam sikapsikap individu terhadap dirinya. Pernyataan serupa juga diungkapkan oleh Lutan (2003) yang memaparkan bahwa self-esteem adalah penerimaan diri sendiri, oleh diri sendiri yang berkaitan dengan kita pantas, berharga, mampu dan berguna, tak peduli dengan apa yang sudah, sedang atau bakal terjadi. Tumbuhnya perasaan "aku bisa" dan "aku berharga" merupakan inti dari pengertian self-esteem.

Self-esteem mempengaruhi motivasi, perilaku fungsional, dan kepuasan hidup, dan secara signifikan berhubungan dengan kesejahteraan sepanjang hidup. Perilaku manusia secara universal ingin mempertahankan dan meningkatkan self-esteem karena sebagai kebutuhan dasar (Greenberg, 2008). Apa yang dipilih untuk 
melakukan dan bagaimana cara mereka melakukannya mungkin tergantung pada self-esteem. Self-esteem yang rendah telah terbukti berhubungan dengan banyak fenomena negatif, termasuk tingginya tingkat kehamilan remaja, penyalahgunaan narkoba, minuman keras, kekerasan, depresi, kecemasan sosial, dan bunuh diri. Faktorfaktor seperti keluarga, jenis kelamin, ras, tingkat ekonomi, orientasi seksual, tampaknya mempengaruhi tingkat self-esteem (Twenge \& Campbell, 2002)

Meningkatkan self-esteem remaja adalah tugas gabungan orang tua, guru, pengasuh, konselor dan kakek-nenek. Beberapa karya terbaik psikolog mengenai self-esteem berada pada hubungan antara anak dan orang tua. Orangtua mempengaruhi tingkah laku dan juga menemukan pentingnya dukungan dan kontrol mereka. Pada bagian ini dibahas dampak dan proses interaksi terkait orangtua-anak, dan menyarankan harus lebih banyak perhatian diberikan untuk remaja aktif, peran hubungan orang tua dengan satu sama lain, dan kemampuan orang tua untuk memberikan pengalaman bersosialisasi yang optimal untuk anak-anak mereka.

\section{Pengertian Self-esteem}

Self-esteem merupakan salah satu faktor keberhasilan individu dalam kehidupannya, karena perkembangan self-esteem pada anak-anak akan menentukan keberhasilan maupun kegagalan di masa mendatang. Sebagai penilaian terhadap diri sendiri, maka pengembangan self-esteem menjadi bagian penting dalam pendidikan karena diharapkan mampu memproses penemuan konsep diri positif pada jiwa Remaja. Menurut branden (2005) self-esteem adalah (1) keyakinan dan kemampuan untuk bertindak dan menghadapi tantangan hidup ini, (2) keyakinan dalam hak untuk bahagia, perasaan berharga, layak. Memungkinkan untuk menegaskan kebutuhan-kebutuhan dan keinginan-keinginan.

Coopersmith (1967) juga menungkapkan self-esteem merupakan evaluasi yang dibuat individu dan kebiasaan memandang dirinya terutama mengenai sikap menerima dan menolak, juga indikasi bersarnya kepercayaan individu terhadap kemampuannya, keberartian, kesuksesan, dan keberhargaan. Secara singkat selfesteem adalah "personal judgment" mengenai perasaan berharga atau berarti yang diekspresikan dalam sikapsikap individu terhadap dirinya. Pernyataan serupa juga diungkapkan oleh Lutan (2003) yang memaparkan bahwa self-esteem adalah penerimaan diri sendiri, oleh diri sendiri yang berkaitan dengan kita pantas, berharga, mampu dan berguna, tak peduli dengan apa yang sudah, sedang atau bakal terjadi. Tumbuhnya perasaan "aku bisa" dan "aku berharga" merupakan inti dari pengertian self-esteem.

Menurut Maslow, self-esteem sebagai suatu kebutuhan yang harus dipenuhi oleh manusia. Kebutuhan akan self-esteem oleh maslow dibagi menjadi dua bagian, yaitu : (1) Penghormatan atau penghargaan diri sendiri yang mencakup hasrat untuk memperoleh kompetensi, rasa percaya diri, kekuatan pribadi, edukasi, kemandirian dan kebebasan. Individu ingin mengetahui atau yakin bahwa dirinya berharga serta mampu mengatasi segala tantangan dalam hidupnya, (2) Penghargaan dari orang lain, antara lain prestasi. Dalam hal ini individu butuh pernghargaan atas apa-apa yang dilakukannya.

Disini individu akan berusaha memenuhi kebutuhan akan self-esteem, apabila kebutuhan akan rasa cinta dan rasa memilikinya telah terpenuhi atau terpuaskan (Koeswara, 1991). Coopersmith (1981) menyatakan bahwa self-esteem individu tidak ditentukan oleh tingginya kemampuan individu dalam sumber self-esteem. Tetapi lebih ditentukan oleh kriteria yang digunakan individu untuk menilai dirinya dan tingkat pencapaiannya.

Dari uraian tersebut diatas, maka dapat disimpulkan bahwa self-esteem adalah : (1) penilaian seseorang secara umum terhadap dirinya sendiri, baik berupa penilaian negatif maupun penilian positif yang akhirnya menghasilkan perasaan keberhargaan atau kebergunaan diri dalam menjalani kehidupan, (2) kemampuan untuk 
memahami apa yang dapat dilakukan dan apa yang telah dilakukan, (3) penetapan tujuan dan arah hidup sendiri, (4) kemampuan untuk percaya pada kemampuan sendiri, dan tidak merasa iri pada prestasi orang lain.

\section{Pembentukan Self-Esteem}

Self-esteem mulai terbentuk setelah anak lahir, ketika anak berhadapan dengan dunia luar dan berinteraksi dengan orang-orang di lingkungan sekitarnya. Interaksi secara minimal memerlukan pengakuan, penerimaan peran yang saling tergantung pada orang yang bicara dan orang yang diajak bicara. Interaksi menimbulkan pengertian tentang kesadaran diri, identitas, dan pemahaman tentang diri. Hal ini akan membentuk penilaian orang lain terhadap dirinya sebagai orang yang berarti, berharga, dan menerima keadaan diri apa adanya sehingga individu mempunyai Self-esteem (Burn, 1993:46).

Self-esteem mengandung pengertian "siapa dan apa diri saya". Segala sesuatu yang berhubungan dengan seseorang, selalu mendapat penilaian berdasarkan kriteria dan standar tertentu, atribut-atribut yang melekat pada remaja akan mendapat masukan dari orang lain dalam proses berinteraksi dimana proses ini dapat menguji individu, yang memperlihatkan standar dan nilai diri yang terinternalisasi dari masyarakat dan orang lain.

Coopersmith (1967) meneliti perkembangan pada anak-anak sekolah percaya self-esteem menjadi fenomena kompleks yang terdiri dari self-evaluation dan manifestasi reaksi defensive untuk evaluasi tersebut. Terdiri dari dua ekspresi bagian-subyektif dan perilaku manifestasi self-esteem adalah self-evaluation kelayakan seseorang. Ini adalah proses "kinerja, kapasitas dan atribut" sesuai dengan standar pribadi dan nilai-nilai yang berkembang selama masa remaja.

Green dan Kolos (2010) menyatakan bahwa pengembangan self-esteem, kompleksitas dari komponen kritis remaja, sesuai dengan pengalaman anak-anak di usia sekolah, yang meliputi : (1) akademik dan evaluasi, (2) partisipasi pada aktivitas ekstra kurikuler dan kompetensi, (3) diterima atau ditolak teman sebaya, (4) kehidupan keluarga dirumah dan hubungan dengan orang tua berpengaruh signifikan. Remaja sering menilai mereka sendiri lebih tinggi dari temannya (Galambos, Barker \& Krahn, 2006). Selanjutnya variabel demografis seperti jenis kelamin, status sosial ekonomi, dan etnis berdampak pada self-esteem.

Violet Oaklander (1988), membuat beberapa daftar pedoman dasar sehari-hari untuk mendukung selfesteem anak, yaitu : (1) mendengarkan, mengakui dan menerima perasaan remaja, (2) memperlakukan mereka dengan hormat, (3) memberikan pujian khusus, (4) spesifik dalam mengkritik remaja, (5) jujur dengan mereka, (6) memiliki reaksi terhadap remaja, (7) memberikan tanggung jawab, independensi dan kebebasan untuk membuat pilihan, (8) melibatkan mereka dalam pemecahan masalah, (9) menjadi contoh yang baik bagi remaja.

\section{Dukungan Orangtua}

Konsistensi formulasi self-esteem menekankan pentingnya penilaian diri, ada bukti persuasif bahwa persetujuan orangtua, dorongan, respons, kehangatan, pemeliharaan, dukungan, dan kasih sayang berkaitan dengan self-esteem remaja, serta aspek lain dari penyesuaian sosial, emosional, dan akademik (Gecas \& Seff, 1990). Untuk alasan teoritis dan metodologis, penting untuk dicatat bahwa self-esteem remaja lebih kuat berkorelasi dengan persepsi remaja dari perilaku orangtua dibandingkan dengan persepsi orang tua itu sendiri (Demo, Small, \& Savin-Williams, 1987). Sebagian besar remaja menghormati dan menghargai orang tua mereka, mengidentifikasi, dan merasa dekat dengan orangtua mereka (Bachman, Johnston, \& O'Malley, 1987).

Dukungan orangtua menunjukkan manfaat bagi self-esteem remaja. Terutama ketika orang tua menunjukkan minat pada anak mereka, menerima, menghabiskan waktu dan melakukan hal-hal bersama, berbicara, mendengarkan, menyentuh, memeluk, bermain, mendorong dan memberikan pujian kepada mereka. Tentu saja, anak-anak sering menolak, mencegah, menantang, dan melemahkan upaya orang tua untuk menjadi 
responsif dalam mendukung mereka (Ambert, 1997), kesesuaian dan pentingnya perilaku orangtua bervariasi untuk self-esteem remaja khusunya dalam menemukan situasi dan tahap perkembangan. Tapi tampaknya yang paling penting untuk self-esteem remaja adalah bahwa mereka merasa bahwa orang tua mereka peduli kepada mereka (Rosenberg, 1985), yaitu bahwa orang tua mereka berpikir mereka penting dan peduli tentang apa yang terjadi pada mereka.

\section{Kontrol Orangtua}

Dimensi perilaku orangtua dengan konsekuensinya yang berpangaruh besar bagi self-esteem remaja adalah kontrol orangtua. Dukungan orangtua, kontrol orangtua bersifat multidimensi, tetapi jenis kontrol orang tua sangat penting. Studi menunjukkan bahwa kontrol otoritatif, menekankan pada penjelaskan penalaran induktif, pengawasan orangtua, pemantauan, dan pembatasan yang lebih positif terkait dengan konsep diri anak, tetapi kontrol otoriter, yang melibatkan pemaksaan, ancaman, dan hukuman fisik, memiliki konsekuensi merugikan bagi evaluasi diri remaja (Gecas \& Seff, 1990). Kurdek dan Fine (1994) mengamati bahwa penerimaan keluarga dan kontrol keluarga yang positif berkaitan dengan kompetensi psikososial (termasuk indeks self-esteem dan selfefficacy).

Kontrol keluarga diartikan sebagai kegiatan pemantauan orangtua yaitu memastikan bahwa remaja mengerjakan pekerjaan rumah, mengetahui di mana remaja dan apa yang dia lakukan, dan menjaga apa yang dilihat oleh remaja. Kurdek dan Fine (1994) menemukan tidak ada batas untuk kontrol, semakin banyak orang tua memantau anak-anak mereka, semakin besar manfaat bagi penilaian anak-anak. Satu penjelasan yang mungkin untuk temuan tersebut adalah bahwa pengawasan orangtua adalah "pengingat harian untuk mereka bahwa orangtua mereka peduli tentang mereka atau anak penting bagi meraka".

Remaja tidak hanya penerima pasif dari perilaku orangtua. Berbeda dengan pandangan tabula rasa yang disarankan oleh teori-teori sosial, adalah umumnya bahwa remaja aktif dan kreatif dalam menentang, menolak, dan menggagalkan upaya orang tua untuk memantau dan mendisiplinkan, mereka menginginkan orang tua untuk menyerah, mundur, sehingga permisif dan toleran. Situasi ini diperburuk dan semakin sulit sehingga memunculkan antisosial, dan pemberontakan remaja tersebut (Ambert, 1997).

Dengan kepribadian mereka sendiri dan dengan banyak pengaruh ekstra membentuk tindakan mereka, remaja mengganggu pemantauan orangtua dan kontrol dengan berbagai cara: Remaja dapat menolak untuk bekerja sama dengan orang tua mereka, dapat memilih untuk tidak taat dengan orang tua yang mencoba mengawasi dan mendisiplinkan mereka, dapat mengabaikan saran, dan dapat tiba di rumah dalam suasana hati yang sangat buruk, mereka dapat badmouth, menghina, melecehkan, dan bahkan menyerang orang tua mereka (Ambert, 1995). Perilaku seperti mengurangi keterlibatan orang tua, dukungan dan evaluasi yang positif dari orang tua membuat remaja bertanggung jawab dalam menyangkal self-esteem yang lebih baik.

\section{Hubungan Orangtua}

Komponen penting lain dari lingkungan keluarga remaja yang berimplikasi untuk self-esteem mereka adalah sifat hubungan orang tua satu sama lain. Tingginya tingkat ketidakbahagiaan perkawinan, perceraian, single parent, dan pernikahan kembali meningkatkan kekhawatiran tentang stabilitas dan kontinuitas hubungan orangtua-anak dan penyediaan sumber daya yang diperlukan seperti sosial, emosional, dan ekonomi bagi kesejahteraan anak-anak. Studi menemukan bahwa tingginya tingkat konflik perkawinan dan interparental mempengaruhi self-esteem remaja, tetapi struktur keluarga (jumlah dan status perkawinan orang tua yang tinggal di rumah tangga) tidak memberikan pengaruh yang signifikan dalam membentuk self-esteem remaja (Cashion, 1984). 
Seringnya muncul Konflik perkawinan dan belum terselesaikan masalah berbahaya bagi pandangan remaja dari diri mereka sendiri dalam beberapa cara. Pertama, remaja, khususnya, cenderung menyalahkan diri sendiri karena interaksi negatif antara orang tua (Hammen, 1992). Remaja sering ditarik ke dalam perselisihan perkawinan, merasa terjebak di antara orang tua dan harus memihak. Selama dan setelah konflik perkawinan, orang tua kurang responsif terhadap kebutuhan emosional remaja, dan mempertinggi konflik (Brody, Stoneman, McCoy, \& Forehand, 1992). Perselisihan perkawinan sering mengendapkan proses keluarga sehingga menjadi destruktif, termasuk agresi interspousal dan kekerasan, konflik orang tua-anak, dan orang tua bersifat agresif dan keras yang ditujukan terhadap remaja (Jouriles, Barling, \& O'Leary, 1987). Dalam situasi ini, pikiran remaja dari keluarga mereka dan diri mereka sendiri mau tidak mau disibukkan dengan hal negatif dan suka mengkritik.

Sekali lagi, penting untuk mengenali sifat dua arah dari hubungan orangtua-anak, dengan remaja sering menjadi sumber, memberikan kontribusi bagi remaja atau eskalasi konflik interparental, menciptakan siklus pengalaman keluarga bermasalah yang menghambat remaja (dan juga orang tua) untuk mengevaluasi diri.

\section{PENUTUP}

Keluarga adalah lingkungan pembimbing yang pertama dan utama, terutama agar kepribadian yang kemudian dapat dikembangkan ke tahap berikutnya. Perkembangan self-esteem sangat dipengaruhi oleh peranan orang tua dalam menjalankan tugas pokok dan fungsinya. Self-esteem merupakan evaluasi yang diuat individu dan kebiasaan memandang dirinya terutama mengenai sikap menerima atau menolak. Hubungan remaja dengan anggota keluarga berhubungan dengan pandangan dan evaluasi dari diri mereka sendiri, dan proses ini tetap berpengaruh sepanjang hidup. Meskipun banyak teori sosialisasi remaja dan pengembangan menunjukkan berkurangnya peran keluarga terhadap remaja sehingga menjauhkan diri dari anggota keluarga, terutama orangtua. Bukti di sini menegaskan pentingnya keterlibatan orang tua, dukungan, dan kontrol bagi self-esteem remaja.

\section{DAFTAR PUSTAKA}

Ambert, A.-M. (1997). Parents, children, and adolescents: Interactive relationships and development in context. New York: Haworth.

Ambert, A.-M. (1995). A critical perspective on the research on parents and adolescents: Implications for research, intervention, and policy. In D. H. Demo 8c A.-M. Ambert (Eds.), Parents and adolescents in changing families (pp. 291-306). Minneapolis, MN: National Council on Family Relations.

Bachman, J. G., Johnston, J. J., 8c O'Malley, P. M. (1987). Monitoring the future: Questionnaire responses from the nations high school seniors, 1986. Ann Arbor: University of Michigan, Institute for Social Research.

Branden, Nathaniel. 1996. The Power of Self Esteem: Health Communications inc. Florida. Deenfield Beach

Brody, G. H., Stoneman, Z., McCoy, J. K., 8c Forehand, R. (1992). Contemporaneous and longitudinal associations of sibling conflict with family relationship assessments and family discussions about sibling problems. Child Development, 63, 391-400.

Burn, R.B .1993. Konsep Diri : Teori, Pengukuran, Perkembangan dan Perilaku. Alih Bahasa oleh Eddy, Jakarta : Arcan. 
Cashion, B. G. (1984). Female-headed families: Effects on children and clinical implications. In D. H. Olson, 8c B. C. Miller (Eds.), Family studies review yearbook (pp. 481-89). Beverly Hills, CA: Sage.

Coopersmith, S. 1981. The Antecedents of Self-Esteem, Palo Alto, CA: Consulting Psychologists Press.

Demo, D. H., Small, S. A., 8c Savin-Williams, R. C. (1987). Family relations and the selfesteem of adolescents and their parents. Journal of Marriage and the Family, 49, 705-15.

Gecas, V., 8c Seff, M. A. (1990). Families and adolescents: A review of the 1980s. In Alan Booth (Ed.), Contemporary families: Looking forward, looking back (pp. 208-25). Minneapolis, MN: National Council on Family Relations.

Greenberg, J. (2008). Understanding the vital human quest for self-esteem. Perspectives on Psychological Science, 3, 48-55.

Green, E.J., Crenshaw, D., \& Kolos, A. (2010). Counseling children with preverbal trauma. International Journal of Play Therapy, 19(2), 95-105.

Hammen, C. (1992). Cognitive, life stress, and interpersonal approaches to a developmental psychopathology model of depression. Development and Psychopathology, 4, 189-206.

Ho, C. S., Lempers, J. D., \& Clark-Lempers, D. S. (1995). Effects of economic hardship on adolescent selfesteem: A family mediation model. Adolescence, 30,117-31

Jouriles, E. N., Barling, J., 8c O'Leary, K. D. (1987). Predicting child behavior problems in maritally violent families. Journal of Abnormal Child Psychology, 15, 497-509

Koeswara, E. 1991. Teori-Teori Kepribadian. Bandung: PT. Eresco

Kurdek, L. A., \& Fine, M. A. (1994). Family acceptance and family control as predictors of adjustment in young adolescents: Linear, curvilinear, or interactive effects? Child Development, 65,1137-46.

McLoyd, V. C, Jayaratne, T. E., Ceballo, R., \& Borquez, J. (1994). Unemployment and work interruption among African American mothers: Effects on parenting and adolescent socioemotional functioning. Child Development, 65, 562-89

Oaklander, Violet. (1988). Windows to our children: A Gestalt therapy approach to children and adolescents.

Rosenberg, M. (1985). Self-concept and psychological well-being in adolescence. In R. Leahy (Ed.), The development of the self (pp. 205-246). New York: Academic Press

Rusli Lutan. (2003). Self Esteem: Landasan Kepribadian. Jakarta : Bagian Proyek Peningkatan Mutu Organisasi dan Tenaga Keolahragaan Dirjen Olahraga Depdiknas.

Twenge, J. M., \& Campbell, W. K. (2002). Self-esteem and socioeconomic status: A metaanalytic review. Personality and Social Psychology Review, 6, 59-71. 